\title{
Between The Lines: Scientific Expeditions in Colonial and Imperial Brazil, and Science History - The Expeditions Undertaken To Espírito Santo
}

\author{
Carlos Roberto Pires Campos, Marcelo Scabelo da Silva \\ (Programa de Mestrado em Ensino de Ciências, Instituto Federal do Espírito Santo, Brazil) \\ (Programa de Mestrado em Ensino de Ciências, Instituto Federal do Espírito Santo, Brazil)
}

\begin{abstract}
An aspect little studied by the historiography regards to the role that the scientific expeditions played to the Science History. These expeditions gave a glance of the Brazilian way of living and specially of the captaincy of Espirito Santo to Europe and helped to build the Brazilian social representations by Europeans, while they set up a notion about the imaginary and how people worked to tame the land and turn it as their needs. Upcoming the science at a contextualized point of view, the purpose of this paper is to present a panel of scientific expeditions undertaken to the Espirito Santo Capitaincy from the sixteenth century to the late nineteenth century, by imperial times, and, in this approach, to highlight the ideological reasons of the mechanisms that led to the occurrence of such expeditions. After the analyses of the travel reports and narratives produced, we realized that the Brazilian Science History was based on the European point of view which influenced the constitution of its cultural diversity. Maybe many of the prejudice against Brazil that has still existed until today originated from these expeditions.
\end{abstract}

Keywords: Cultural diversity, Scientific expeditions, social representations, Travel Narratives

\section{Introduction}

Based on the context of Brazil's history, we can understand the term "scientific expedition" as events in general, organized and integrated by European, which aimed to explore, to understand and to analyze the things, the land and the people who inhabited Brazil during the period of three centuries of colonialism (Fetz, 2011). Travel and expeditions soon started just after Brazil's Discovery in the early sixteenth century, all moved after curiosity and some of them with scientific inclination (Belluzzo, 1996).

In the transcourse of the Brazilian colonial period, scientific research took place in a very incipient manner, except for the period of Dutch occupation, especially during Mauritius of Nassau (1604-1679) management in Pernambuco (1637-1644), which attracted to Recife scientists articulated to the nascent modern science of the seventeenth century (Whitehead; Boeseman, 1989). In the nineteenth century, with the change of the Portuguese royal family to Brazil, a more systematic process of study and research of flora, fauna, geography and social life of the country started (Ruiz, 1986). We point out the year 1808 as a milestone in the history of national scientific research, with the installation of the Portuguese court in Rio de Janeiro (Belluzzo, 1994). The opening of the Brazilian ports in the same year favored a shift in the colonial status, which restricted the foreign trips across the country. This port opening made it possible for both artistic expeditions and scientific ones which were undertaken in order to register and to collect natural specimens and objects, some of which were commonly referred to European museums or protected by scientists and naturalists in their private collections. So begins the science in Brazil, and only from this perspective it is possible to understand the history of Brazilian science.

In order to develop a contextualized discussion, our observations of science, and the expeditions that it motivated, will seek to situate it from its socio-historical context, considering that in each situation, imaginaries were constructed, speeches were created and so were social forms of action ordering people's life. From this perspective, we can understand that we live in eminently cultural worlds, which are configured as contingent artifacts of our creation (McGuire; Tuchanska, 2013). Hence, this article seeks to present, in a panoramic way, the main scientific expeditions organized to Brazil, specifically the ones elapsed in the territory of the Province of the Espírito Santo. This was the criteria used to define the approach, besides the relevance of the issue. In this snip, we will point out possible relationships between the type of science conducted at these events and their social and political reasons, focusing the cultural diversity of the land where the scientific expedition was conducted.

This is a complex subject, especially for the lack of studies about the Brazilian scientific scenario in the colonial period, so we will not lose the opportunity to highlight the relationship between science and its various embodiments intersect with the sphere of culture. Considering the Brazilian singular historical context, 
in its early moments, Brazilian science appropriated in its discourse the culture and the popular knowledge. Science used plastic arts and the literature as epistemological tools, although they possessed different languages and dictions, one appropriated of another in order to produce social sense. This interaction produced a certain social dimension to science and a scientific dimension to the literature, what benefited both of them. The Letter of Pero Vaz de Caminha, for example, was not written to become the foundation narrative of Brazil. It had a communicative intention, to report to the king of Portugal what existed in the new land discovered in $21 / 04 / 1500$. However, today, it has become both a historical document, and a literary and scientific one. It is important for the History of Science because it contains scenes of a scientific description of the peoples, plants and animals. Despite all this, the fact is that science in Brazil effectively started only in the first decades of the nineteenth century, when the Portuguese royal family arrived in Rio de Janeiro, fleeing from Napoleon's army invasion in 1807 in Portugal. Until then, Brazil was nothing but a poor colony with religious institutions commanding its education, whose science was based on scholastic philosophy. No universities, no press, no libraries, no museums existed in Brazil until 1808, in a stark contrast to the colonies of Spain, who had universities since the sixteenth century. The Brazilian population was full of gossipers, selfish and fortune hunters. Perhaps this was a deliberate policy of the Portuguese colonial power, fearing the appearance of educated Brazilian classes, driven by nationalism and other aspirations that could seek for political independence.

\section{Methodology}

This Study Adopted The Qualitative Research Approach, and the case study design was used. The qualitative research paradigm was appropriate because there was a social-historical problem to be discussed which demanded also to be understood in its details. For the organization of this study, the starting point was a research of bibliographic material which would contemplate the key-words "scientific expeditions", "travel narratives" and "scientific expeditions in Espírito Santo, Brazil." From these three key-words, we researched for books, articles and papers at the Special collection of the Sectorial Library of Federal University of Espírito Santo, Brazil, We also researched in Capes Portal databases, in the Indexing databases of Google Scholar and Scielo. For the historical documents, we conducted a research in the Public Archives of Espirito Santo State. The objective was to collect material, to analyze information and to construct knowledge about the facts. Twenty-three texts were found. The next task consisted of reading them to identify whether they contained scientific expeditions that passed by the territories of captaincy of Espírito Santo, Brazil. The proposal was to locate and obtain the relevant documents concerning to the subject, to organize a basic bibliography. Six texts that dealt with this matter were selected, what permitted us to develop a provisional layout work. The next task was to assess the dialogue between the texts, avoiding unnecessary repetition. In the library of the Federal University of Espírito Santo, three books on scientific expeditions were localized, which were added to the collected material. Then data were transcribed, summaries were written and notes were taken, and this literature was enriched with explanations, aiming to articulate the text to the theoretical issues.

The analytical procedure adopted included reading and rereading the transcript data in order to generate interpretations from the relationship between the different types of elements. The discussion of the data consisted in a content analysis. Establishing associations between issues and themes, it was possible to construct categories for building the approaches. The proposal was to articulate more specific factors to general, such as science, travel etc. This strategy sought to reduce the complexity of the localized texts, bringing to the public items that could present a historical panel without excessive reductionism, to allow a broader view of the set of episodes related to scientific expeditions. Among the indicators that were used during the content analysis, which dictated the text organization, we cite the three categories of analysis: scientific expeditions, science history and cultural diversity. These beacons allowed organizing the information for the writing of this article, which contains different contributions from different authors on the subject. So we consulted primary sources and carefully selected secondary sources, on which we printed out our analysis.

\section{The Scientific Expeditions}

The curiosity for the exotic brought to Brazil travelers seeking to describe its natural environment and its social life in the early years of its discovery. Travelers produced reports, from which, since the sixteenth century to the nineteenth century, Europe built the idea and social representations about Brazil. The first expedition undertaken in Brazil was the one conducted by Martin Afonso de Souza, elapsed between 1530 and 1532, who founded the first village in Brazil, the village of São Vicente. The expedition passed from Maranhão to the River Plate and through Espírito Santo. The lack of mineral wealth, as reported, meant that Portugal tilt its interests for farming of sugar cane (Saccharum officinarum) and for exploitation of Brazil wood (Caesalpinia echinata), in this case, seeking both the quality of the wood and the dye extracted from its bark, because the red colour, in the sixteenth century, was the European monarchy color, expressing power and wealth (Bueno, 1998). 
Between The Lines: Scientific Expeditions In Colonial And Imperial Brazil And Science History...

One of the first foreigners to be in Brazil was the German explorer Hans Staden, who, despite not having been in the captaincy of the Espírito Santo, deserves mention for taking part, in favor of the Portuguese, as an ally against an indigenous uprisings. Starting from Bremen, in the current Germany, came to the captaincy of Pernambuco in January of 1548, even before the Jesuit mission, which arrived in 1549 in Salvador. The Portuguese ship in which Hans Staden was traveling sought to collect Brazil wood (Caesalpinia echinata), and also fight against any French ships that would try to negotiate with the natives. We cannot miss to mention that the galleons of the first trips to Brazil used to carry shipwrecked, exiles, witches and gypsies condemned by the Portuguese Inquisition, sent to live in the settlements and to populate the colony. These individuals brought with them knowledge, world knowledge about plants and animals, which were socialized, in later times, to Brazilian residents (Bueno, 1998; Pieroni, 2002).

Hans Staden published the book Two trips to Brazil in Magdeburg, Germany, in 1557. This book met successive editions, configured as a publishing success because of its illustrations of animals and plants and the descriptions of cannibal rituals and land customs. Such descriptions created in the European imaginary of the sixteenths social representations that Brazil was a country of cannibals, a land of savage devourers of human flesh. The Science history, however, nowadays, prefers to look at this book from anthropological and sociological interests, because it describes methods for plant domestication and primitive forms of land management and use, and the answers that the land used to give for these uses and occupation. The book also emphasized the forms of sociability, through the study of religious rituals and its complex symbology, representing the sixteenth century (Pereira, 2001; Staden, 2010).

Based on the assumption that the interpretations undertaken at this new work were based on the Bible, as the revealed truth, it is possible to think that this revealed truths forced men to travel to America in order to search for new interpretations, seeking answers to some intriguing questions, the type, who was the American man? How Noah's ark landed in America? How the American man got there? Who redeemed the American man? Having God created only one man, how would be the American phenotype? Trying to answer to these questions, the Jesuits accompanying Duarte da Costa in 1549 were aware of the challenges that were awaiting them in the tasks of catechesis and in the land domestication. The Jesuits, in general, believed that the American man had come to America through Siberia. Once arrived in Brazil, they soon started to describe indigenous customs, their crops methodology, their domesticated animals and their religious rituals, especially the beliefs and their imaginary. The first Tupi-Guarani (their language) Grammar was written by a Jesuit in 1595. These works produced by José de Anchieta, Manuel da Nobrega, among others Jesuits, offer a wealth of detail about ways of doing science in the Brazilian sixteenth century (Leite, 1949).

A naturalist traveler who passed the captaincy of the Espírito Santo was the Jesuit Fernão de Cardim, who was born in mid-1543, in Viana do Alvito, Alentejo, Portugal, belonging to the Archbishop of Évora, Portugal. He joined the Society of Jesus in 1556 and died in Brazil, Vila de Abrantes, in 1625, as a victim of the Dutch invasion in Bahia (Leão, 2005). The main source of research for Cardim report consists of two epistles in the book Tratados da Terra e Gente do Brasil, published for the first time in 1847 by Francisco Adolfo de Varnhagen, under the title "Narrativa Epistolar de uma Viagem e Missão Jesuítica pela Bahia, Ilhéus, Porto Seguro, Pernambuco, Espírito Santo, Rio de Janeiro, S. Vicente, desde o ano de 1583 ao de 1590, indo por Visitador o Padre Christóvão de Gouvêa". The first epistle was written on October, 16, 1585 and the second was written on May, 1, 1590. These narratives were published again in Rio de Janeiro, in 1925, included a work dedicated to Cardim, together with other texts of his, entitled Tratados da Terra e Gente do Brasil with a careful literary critic in the introduction and notes written by Baptista Caetano, Capistrano de Abreu and Rodolfo Garcia. In this book, included are other Cardim texts, namely: "From the beginning and origin of the Indians of Brazil and its customs, worship and ceremonies" and "The climate and soil of Brazil and some remarkable things which are on earth and at sea". Such narratives reveal an accurate description of the Portuguese America social and economic situation in the late sixteenth century and the Company of Jesus catechetical action in Brazil. The design of the land includes elements as climate, soil, flora and fauna as well as their usefulness for food, medicine and social interactions. Highlighting not only issues related to catechesis, the cardinian texts considered as well important the land potentialities and the animals, plants, their medicinal use in disease situations. Cardinian narratives contemplate carefully crafted descriptions, bordering on scientific analysis, which demonstrated concern notify the colonial situation in its smallest aspects (Cardim, 1997).

Gabriel Soares de Souza was a traveler who came to Brazil between the years of 1565 and 1569 and, in Bahia, has established himself as settler and soon became owner of a sugar mill. He got funding for his trips and published a very significant work about Brazil. The originality of his work was highlighted in his book Notícias do Brasil, published in 1587, which can be divided into two parts, the first tells all that existed in Brazil and the second focuses the greatness and richness of Bahia. In the book, the journey begins on the Amazon River and goes down to the Rio de La Plata, in Argentina, in which course the traveler tells the stories of tupinambás, the tamoios, the tapuias and other indigenous nations. Tells what they ate, how they did it, how they hunted, their way of fighting, which plants they grew, tells about cassava (Manihot esculenta), papayas (Carica papaya), cashews (Anacardium occidentale), vegetables, pepper (Capsicum frutescens), amphibians, snakes, boa constrictors, apes, and that weaving stories abound fantastic tales and exotic narratives of the earth (Souza, 1938).

Pero de Magalhães Gandavo, a Portuguese scientist, professor of Latin, traveled to Brazil between 1558 and 1572, in whose expeditions gathered enough data to write his famous work História da Província Santa Cruz a que 
Between The Lines: Scientific Expeditions In Colonial And Imperial Brazil And Science History...

vulgarmente chamamos Brasil, published in Lisbon by Antonio Gonçalves, in 1576. One should highlight that this was the only work published concomitantly to the period that the actions narrated happened. The intention was to make a propaganda of Brazil in order to encourage to live there. That means that the time of enunciation of the narrative is contemporary to the time of publication. Normally the other books would be published years or decades after it has been written. In his book, Gandavo presentes a geographical description, with a number of fauna details, including the anteater that calls tamanduá (Myrmecophaga tridactyla), armadillos (Dasypodidae), a number of birds, insects and exotic fish, all of them, at that time, unknown to Europeans. He described Brazil as a wonderland, with his strangeness and wealth. The plants of the colony also earn his attention, receiving special tonic cassava (Manihot esculenta), base of the Tupi-Guarani subsistence. Gandavo presents the plants, followed by their utility. In addition to reporting aspects of fauna and flora, it stands out how Brazil's discovery occurred, how it was in the early years of the Colonial Times, the various Indian tribes and how and why Brazil's territory was divided into hereditary captaincies. The meeting between the Amerindians and the Portuguese was also presented in details (Gandavo, 2008). The author tried to review a general scenario of the potentialities that the land reserved to the Portuguese, the vastness of the territory and its economic resources. It is worth noting the curiosity that marked the scientific expeditions of the sixteenth century, religiosity, ethnocentrism and a strong articulation between science and popular knowledge were also registered marks. The book points out medicinal plants and planning methodologies for the land settlement, in an agronomic perspective. However such work today constitutes itself in a valuable source of studies for the Science History, if we analyze from the social context in which it was produced. We have to consider that in the sixteenth century modern science was still in its initial breath.

The seventeenth century can be understood as a rather complicated period for the Portuguese Colonization in Brazil, this, considering the Dutch invasions, The French pirates, the Iberian union between Spain and Portugal from 1580 to 1640, the decline of the overseas trade with the Indies, among other events (Boxer, 1961; Mello, 1998). The Dutch stormed the coast of the Espírito Santo captaincy coming from Zeeland and commanded a violent and bloody attack on the capital in 1625. On March 12, they invaded Vitoria, the capital, under the command of Piet Heyn. The church bells called the population for participating in the defense of the island (Roos; Eshuis, 2008). Not only the Portuguese soldiers, but also civilians of Vitoria, the Jesuits of the St. James College, and a group of Indians led by cacique Japi-Açu and Big Cat defended their city and fought against the Dutch to retreat them. The only Dutch attempt that had some success, in the Espirito Santo Captaincy, occurred more than twenty years later, which resulted in a withdrawal to the Penha Monastery in 1653, taking works of art, sacred arts and gold coins. However, whether they produced reports about what they had observed in the land, we couldn't find those documents in the Public Archive of Espírito Santo. The State Public Archive managed to receive from the University of Amsterdam nearly all the documents and reports about the West Indies Company, belonging to the Dutch merchants of the seventeenth century, but these historical reports didn't contain data about the Dutch invasions to the capitaincy. On the other hand, the period of the Dutch occupation in the Northern of Brazil represented fifty years of great scientific progress, regarding to the social order and the production of technologies for management of the territory. Innovations in the agricultural methods improved the sugar cane production, and the establishment of agreements with other Dutch companies brought to Brazil intelectuals, scientists, naturalists, artists, among others. For the rest of the seventeenth century there weren't scientific expeditions registered in the historical documents consulted.

In the early eighteenth century, the Portuguese economy was in a complex situation because of two great invasions, which suffered Brazil in the previous century. Besides, the violent earthquake and tsunami that devastated Lisbon in mid-century weakened even more the Portuguese economy. Because of these crises in the eighteenth century, definitely, Portugal became dependent of the English banks. The signing of an agreement in 1703 for the purchase of manufactured goods made the Portuguese and the Brazilian economy dependent on England. The mining cycle in the following decades would provide some relief to the Portuguese finance, but, on the other hand, it closed the Espirito Santo coast at any travel and shipping, avoiding entries for Minas Gerais, where swarmed the mining of gold and precious stones (Hollanda, 2004) . Regarding to the scientific expeditions, there were several travels to Brazil with this purpose, the problem is that those reports were not published. It's known however that to the captaincy of Espírito Santo there were no entries. As the coast of Espírito Santo served as guardian to the mines, any attempt to dock in its capital, Vitoria, would be unsuccessful. The only mention it was possible to locate in the documents consulted was an expedition conducted by the English Captain James Cook - the discoverer of Australia - whose manuscripts are preserved in the Portuguese archives, especially in the archives of Torre do Tombo in Lisbon. This was the eighteenth century panel. While gold and precious stones from Minas Gerais were drawn to finance the construction of the convent of Mafra, in Portugal, with opulence and wealth, and for the reconstruction of Lisbon with bold lines, following the neoclassical architectural pattern, part of this wealth was used to pay off debts of Portugal with England. Certainly England may have used these funds to finance its Industrial Revolution in the late eighteenth century.

According to Fetz (2011), scientific expeditions and travel narratives resulting from them multiplied in the Brazilian nineteenth century, with the economic and political openness, resulting from the Portuguese court change, in the year 1808, to Rio de Janeiro. This event triggered a large increase in travelers and naturalists to Brazil, including Charles Darwin, who berthed with the Beagle in Rio de Janeiro, in April, 1832. These expeditions were conducted by 
Between The Lines: Scientific Expeditions In Colonial And Imperial Brazil And Science History...

teams, and headed generally by a renowned naturalist. Traveling next to the scientist, assistants, biologists and artists, the latter being in charge of producing the pictorial environment reproduction and the population daily, or images of the visited places, usually made through a specific type of landscape painting (Fetz, 2011 p.49).

Many were the expeditions undertaken to Brazil in the XIX century, some of them were undertaken to Espirito Santo Capitaincy. We can quote the expeditions led by Maximilian Wied Neuwied in 1816; Auguste Saint-Hilaire in 1818; François-Auguste Biard in 1858; Jean-Jacques Tschudi in 1866; Charles Frederick Hartt, in 1870; and one led by the Princess Theresa of Bavaria, in 1888. The next part of the article aims to present some of the nuances of these expeditions and move towards the closing, in which conclusions about the process will be highlighted.

The nineteenth century gathers the greater number of Scientific expeditions because of two facts, first because they were supported by economic and scientific interests and second because of the Brazilian ports opening made it easier to organize the travels. The travelers, affiliated to collectionism, arrived looking forward to the encounter with the unfamiliar environment and, especially, were moved by curiosity to establish contact with the ex-optical native people. The Museum of Natural History, as we know it today, is the result of the enlightenment of the eighteenth century, but there was also a desire for office collections, which housed private collections. Naturalists, Archaeologists, Princes and Princesses and also the State became fierce collectors, guardians of archaeological relics, of stuffed animals and plants, and paleontological specimens from distant lands. The collection served as a form of social legitimacy, since every member of the elite wanted to be seen as a protector of the arts and guardian of science. In general collections served as a kind of store of value (Trigger, 1989).

In a scientific expedition whose assumption was based on the German Naturalist and Geographer Alexander Von Humboldt, Prince Maximilian Alexander Phillip, the Wied Neuwied Prince, between 1815 and 1817, traveled to the Espírito Santo and Bahia accompanied by Freyreiss and Sellow, publishing, then, the book Journey to Brazil, (Reiss nach Brasillien). In these reports we should highlight the visits performed to the settlers homes, to the farms and to other places. It is important to mention a visit by the Prince to a Jesuitical Farm called Muribeca, in the southern part of the province of Espírito Santo. At the time, the land in question no longer belonged to the Jesuits, but the prince's testimony brings up relevant aspects about the farm dynamics. Prince Phillip tells us about the forests, mangrove, lagoonal deposits, floodplain, the extensive sugar cane plantations and the people, inhabitants of the land. The Prince reported that all around, huge forests limit the horizon. Many slaves, who worked on the plantations, looked with amazement at our troops, out of the forest like an apparition of the New World. It is reported that the work in that farm is very hard for the slaves, mainly consisting in breaking down the forests, chopping the trees. In the farm they planted cassava, maize, cotton and some coffee (Phillip, 1940, p.123).

It is possible to analyze the Prince report as a typical narrative of the Romanticism, a cultural movement that, in the late eighteenth century, had begun in Germany, under the aegis of a desire for freedom, seeking his idyll in places not contaminated by the forces of induced consumerism, the proliferation of manufactured goods on the market and the urban luxuries. The Liberal Revolution was the political movement of the romantics which supported the daring spirit, aiming to reach the origins of man and the ideas of freedom. The monarchy and the intellectuality believed in myths, they tried to rescue the exotic cultures, the lost narratives, they appreciated the nature, the forests, the rivers and mountains. The nature, coated with pure values, caused the incantations and contemplations. The Romanticism also encouraged the nobles to take risks in adventurous attitudes, because there was, then, an overvaluation of the potentialities of man as wild territories trailblazer. The society and nature came to be understood as individual properties, not vice versa.

Prince Wied Neuwied came to Brazil to meet an exuberant nature, and in his discourse it is possible to note brands of the Romantic Movement. A different nature and mighty, exalted in its maximum expression, endowed with colorful hues, it seems to come to life under the gaze of the European naturalist. And the description of the natural scenario shows more relevant to the prince that the very people who inhabited it. The narrator prioritize the surroundings and the great forests inhabited by wild Puri indians, which still practiced cannibal rituals, according to reports made by the settlers to the German prince. In analyzing the situation, the Prince recognizes that the hostility of the Indians was due to the way they were treated by the settlers in their greed for wealth. As a result of the expedition to Itabapoana river, the naturalists have identified several animals, including the íbis (Threskiornithinae), musk ducks (Cairina moschata), herons (Pilherodius pileatus), great egrets (Ardea alba) and otters (Lutrinae). For the German Prince, it was significant the awakening of sensitivity caused by sensorial experience due to the direct contact with nature, especially by the adventure and by the dynamism of the quest for knowledge. Instead of experiencing cities, equal in everything, including the streets, the trains, the pollution, instead of experiencing urban routines, with repetitive motions such as machinery, Prince Phillip sought the exotic for understanding the wildlife, maybe for understanding himself, in a journey to the frontiers of his fears and limits.

Another expedition, not least important, was led by the French botanist Auguste Saint-Hilaire, who was in Brazil between 1816 and 1822, during which toured much of the Brazilian coast, reaping zoobotanic information to the French Natural History Museum in Paris. His journey to the Espírito Santo Province was undertaken in 1818 when he visited cities and towns, restricted to the coast, going from Barra do Itapemirim to the delta of the Rio Doce, covering nearly $150 \mathrm{~km}$ of littorals. His data were gathered in two books Travel to the diamond district and to the coast of 
Brazil and Second trip to the interior of Brazil. Due to the richness of his reports, Saint-Hilaire, besides describing in detail each settlement and city, highlighting the quantitative of the population at that time and the houses, types of buildings, cultural aspects and the economy, also commented on the history of the captaincy since from the arrival of the first donee. For this task, we used the information from several historians of the time and travelers who had passed before him to the captaincy. In his reports it is possible to derive important information about the natural aspects of the province, as well as reports of clashes involving indigenous peoples, settlers and representatives of the provincial government (Saint-Hilaire, 1936/1941).

In a 1818 report, he pointed out cannibalism practices and the state of hostility the Puri indigenous were lived in the region, a fact that coincides with the narrative of Wied Neuwied. He makes mention of a military post in the community now known as Quarteis, which had the mission of protecting the coast against pirates. This garrison was aimed at protecting the South of Espírito Santo coast, halfway between the delta of the Itapemirim and Itabapoana River. A search for oral sources revealed that the former barracks that the traveler reports make mention was situated on the coastal plain, in the board of the Barreiras Formation, in the south coast of Espírito Santo, about ten kilometers from the Itabapoana Delta, following the coast northward. The problem is that the cliff suffers directly an erosive action by the sea, which shapes the coastline, opening beaches ridges and forming beach deposits. This dynamic of the shore line changes with time, and the old barracks that travelers make mention exist no longer, because it was located on the top of a cliff which was eroded. The sea has eroded more than two hundred meters of cliffs in two centuries, according to reports from local geologists and according to the geological reports about the oscillation of the sea level during the Holocene.

The Romanticism main feature was the purity of the soul, this was the special color of the cultural movement, whose tonic was the organic and the transformer development. With this, the Romanticism wanted to infuse the culture to nature, against external devices, in order to give rise to a new kind of community. This allows us to reflect on the report of the French scientist as a narrative of literary nuances, endowed with a look dotted with the romantic imagery, with subtle markings of some categories such as nature as a locus amoenus.

Another important expedition to Brazil, and specifically to Espirito Santo Province, was led by FrançoisAuguste Biard who was born in Lyon in October 8, 1798 and died in Fontainebleau on June, 22, 1882. He was a naturalist and a French painter who traveled by Brazil between 1858 and 1859, having pas sed through Rio de Janeiro in May 1858, where he painted portraits of the Imperial Family. Then he traveled to Espírito Santo and to the Amazon, to the cities of Belém and Manaus, coming to undertake an expedition through the Madeira River, returning to Belém, from where he returned to Europe in November 1859 (Biard, 1862). On his journey, collected birds, shells, animal skins. As a result of his journey, he published the book Deux années au Brésil in Paris in 1862. For not having a formation of a naturalist, his work had little scientific relevance.

Jean-Jacque von Tschudi, who studied medicine and natural sciences but was also an anthropologist, naturalist, philosopher and traveler, can be recognized as a true intellectual of his time. Descendant of a traditional Swiss family, born in Glarus, 1818, after attend Social Sciences and Medicine, took a boat in France to travel around the world in a study tour. By fortuitous circumstances, he stopped in Peru for five years, where he had time to study and write three books Research on the Peruvian fauna; Quichua language system and Peruvian Antiquities. About Brazil and notably about the Espirito Santo, where he was mainly to visiting the Swiss immigrant colonies in Rio Novo do Sul, he wrote the book Reisen duren Sud America, published in Leipizig in 1868, which provides rich information about the methodologies for the occupation of land, plants and crops, animals and other topics not less important. This work was written in German, and a few years ago, some of the Federal University of Espírito Santo professors of History Department were encouraged to translate it and socialize it to the interested public. Then, financed by the Public Archives of the Espírito Santo, a book was organized with the title Viagem à Província do Espírito Santo: imigração e colonização suíça, 1860 (Travel to the Province of the Espírito Santo: Immigration and Swiss colonization, 1860). The book, with Tschudi's drafts, contains scenes of the everyday life of the first years of Swiss immigrants in Espirito Santo. Designated by the Switzerland Government to investigate the living conditions of immigrants in South America, in the 1860s, Tschudi narrated the precarious conditions in which lived the first Swiss in the state and how they would domesticate plants, how they ordered the occupation of the land and the techniques to produce popular science (Tschudi, 2004).

Charles Frederick Hartt was born on August 23, 1840, in Fredericton, New Brunswick, and died on March, 18, 1878, in Rio de Janeiro. He was a Canadian-American geologist. Followed by Louis Agassiz, who was a student in his trip to Brazil in the Thayer expedition, during which they explored the Brazilian coast, between Bahia and Rio de Janeiro, bringing together a large collection of zoological and paleontological specimens, soon becoming an authority on Natural History in South America. From 1876 on, Hartt served as the director of the National Museum of Rio de Janeiro, to which he donated his important geological collection, which, until today, has made up the museum mineralogy collection. During the years of 1875 to 1877 , Hartt was coordinator of the Geological Commission of the Empire of Brazil, which was established by the Emperor D. Pedro II, and had as its primary focus on the study of geology, paleontology and Brazilian mines (Thames; Hudson, 2007). 
Teresa Charlotte Marianne Auguste, born in Munich, was the daughter of King Leopold, who took the throne of Bavaria kingdom in 1886, ruling until 1912. She was a self-taught scholar with an interest in botany, zoology, geography, natural history and languages. In 1888, Princess Teresa visited the Espírito Santo and ran rivers, forests, villages and kept in touch with Botocudo indigenous at the river banks of the Rio Doce, leaving written her experiences and impressions. The notes gave rise to the book, published in Berlin in 1897, entitled Meine Reise in den brasilianischen Tropen translated, organized and reissued in 2013 by the Public Archives of the State of Espírito Santo (APEES), with the title Viagem ao Espírito Santo - 1888 (Journey to Espírito Santo, 1888). Teresa arrived in Brazil with a chaperone and two assistants, one with taxidermic skills - Art stuffing, a painter and photographer. She was carrying photographic equipment and used to hire local guides in their wanderings through the forests. In addition to the observation of Botocudos Indians - central concern of her expedition - she performed a meticulous work, inventorying, cataloging and archiving specimens, some of them taken to her private collection (Baviera, 2013).

Some expeditions become renowned for their scientific results, many of which serve today as source for historiography, permitting a glance on the everyday life of the late nineteenth century, its thought, imaginary, and the form of dominating the nature. Regarding to the Science history, specifically, the reports elaborated in the course of scientific expeditions work as a tool for critical understanding of science and society through the colonial and imperial centuries. The question everyone would like to get answered is how Brazil's image has been built in Europe and whether these social representations still persists to nowadays, considering that many Europeans still articulate the image of Brazil to a place of superstitious people of savage habits. In which proportion did the Scientific expeditions conduced to Brazil contribute to produce or to forge these social representations?

\section{Conclusion}

Studying Brazilian national stories is both complicated and attractive, perhaps at another time, with more breath, we can enter the universe of diversity to study how this issue was seen by Europeans who walked around here. Understanding how this look from outside guided the discussions of the concept of social diversity in the European scientific environment shows up as a challenge. Travel narratives are revealed as a literature that reports the struggles, the challenges and achievements of scientific expeditions in the colonial and imperial centuries in Brazil. The naturalist and the traveler figures are therefore crunch for these studies. It is through the European point of view that we will know the first Brazilians. We don't possess a report written by a Brazilian detailing the Brazilians. It is from the Science man, the traveler and the naturalist understanding that we get to know the first Brazilians and the thought style that justified the representation of social diversity, especially the images described by the European traveler of the culture and the society.

In the sixteenth, eighteenth and nineteenth centuries Brazil received dozens of foreign travelers crossing the country in search of knowledge of the lands and peoples of the New World. Almost all of the collected material, however, turned to institutions in the countries of origin of the scientific missions. Only a few of us know, on the other hand, that the Brazilian imperial government, with the objective of creating a national science, instructed a group of Brazilian scholars to travel around making collections, exams and trials, work so far carried out only for foreign missions.

The great purpose of the European expeditions seems to have been the curiosity about the Indians and their behavior. The way to do science, how the narratives were produced little dialogued with modern science and most transited in the literary field and religious beliefs. In this it seems to be stuck how to look Brazilian cultural diversity. Maybe these social representations created by the Europeans about Brazil still persist.

Studying the scientific expeditions undertaken in the territory of Espírito Santo means an effort to try to understand the history of Science in that context. We close our article with a reflection proposed by McGuire and Tuchanska (2013 p. 175): The past of science is simply not an objective temporal sequence of separate events of contemporary science. The past of science must be seen in its dialectical connection with modern science and philosophers and historians of contemporary science. Since we do not belong to the past of science, we can only contemplate it from the present, but this may hold the key to the interpretation of the past. The past of science is the basis of our current science. Maybe the upcoming science will be less political, more neutral, less capitalistic, more concerned with the happiness and quality of life of man, proposing more tolerance for differences and a harmonious coexistence with nature.

\section{Acknowledgements}

A special thanks to my Coordinator, Prof. Dr. Sidnei Quezada Meireles Leite for trusting in my work A special thanks to my mother Maria Regina for helping me to organize this article.

\section{References}


Between The Lines: Scientific Expeditions In Colonial And Imperial Brazil And Science History...

[1] M. FETZ, Expedições científicas no século XIX: o universo da ciência e a diversidade cultural, Cadernos de Campo, 20, 2011, p $39-54$

[2] A.M. BELLUZZO, A propósito do Brasil dos viajantes. Revista USP, 30, junho - ago, 1996 p. 8 - 19 ,

[3] P. J. WHITEHEAD, and M. BOESEMAN, Um retrato do Brasil Holandês do Século XVII. Animais, plantas e gente pelos artistas Johan Mauritz de Nassau. (Rio de Janeiro: Kosmos, 1989)

[4] E.A. RUIZ, Expedições científicas, descobrimentos geográficos e expansão política: Os Estados Unidos e a América Latina no Século XIX. Geosul, n.2 ago-dez, 1986, p. $79-93$

[5] A. M. BELLUZZO, O Brasil dos Viajantes (São Paulo: Metalivros, 1994)

[6] J. McGUIRE and B. TUCHANSKA. Da ciência descontextualizada à ciência no contexto social e histórico. Revista Brasileira de História da Ciência, Rio de Janeiro, v. 6, n. 2, 2013, p. 151-182

[7] E. BUENO, Náufragos, Traficantes e Degredados: as Primeiras Expedições ao Brasil, 1500-1531 (Rio de Janeiro: Objetiva, 1998)

[8] G. PIERONI, Vadios e ciganos, heréticos e bruxas: os degredados no Brasil - colônia (Rio de Janeiro: Bertrand Brasil, 2002)

[9] P.R. PEREIRA, Brasiliana da Biblioteca Nacional (Rio de Janeiro: Nova Fronteira, 2001)

[10] H. STADEN, Duas viagens ao Brasil (Porto Alegre: L\&PM, 2010)

[11] S. LEITE, História da Companhia de Jesus no Brasil (Rio de Janeiro, Civilização Brasileira, 1939 V. VI Tomo II)

[12] L.C. LEÃO, Relatos do Padre Fernão Cardim (1583-1625): Missionação no Brasil da Contra Reforma. Monography, Federal University of Paraná, Brazil, Curitiba, 2005

[13] F. CARDIM, Tratados da Terra e Gente do Brasil. Edited by Ana Maria de Azevedo (Lisboa: Comissão Nacional para as Comemorações dos Descobrimentos Portugueses, 1997)

[14] G. SOUZA, Tratado descriptivo do Brasil em 1587. 3.ed. (Rio de Janeiro: Companhia da Editora Nacional, 1938)

[15] P. M. GÂNDAVO, História da Província Santa Cruz a que vulgarmente chamamos Brasil (Brasil: Senado Federal, 2008)

[16] C.R. BOXER, Os holandeses no Brasil (1624-165.(São Paulo: Companhia Editora Nacional, 1961)

[17] E. C. MELLO, O Negócio do Brasil. Portugal, os Países Baixos e o Nordeste, 1641-1669 (Rio de Janeiro: Editora Topbooks, 1998)

[18] R. S. T. ROOS and M. ESHUIS, (Eds.). Os Capixabas Holandeses Uma história holandesa no Brasil. Tradução da língua holandesa Op een dag zullen ze ons vinden. Ruth Stefanie Berger Ton Roos e Margje Eshuis (Vitoria: APE Edição comemorativa dos 150 anos da colonização holandesa, 2008)

[19] S. B. HOLLANDA, História Geral da Civilização Brasileira 11.ed. (Rio de janeiro: Bertrand Brasil, 2004)

[20] B. TRIGGER, A History of the Archaeological Thought. 2.ed. (Cambrige: Cambrige University Press, 2006)

[21] M.A. PHILIP, Prínce of Wied-Neuwied, Viagem ao Brasil (São Paulo, Itatiaia, 1940)

[22] A. SAINT-HILAIRE, Segunda Viagem ao Interior do Brasil, Espírito Santo Tradução de Carlos Madeira. (São Paulo: Companhia Editora Nacional, 1936/1941)

[23] F. BIARD, F. Deux années au Brésil. (Paris: Librairie da La Hachette et C, 1862)

[24] J. J. von TSCHUDI, Viagem à província do Espírito Santo: imigração e colonização suíça 1860. Coordenação editorial e posfácio de Cilmar Franceschetto (Vitória: Arquivo Público do Estado do Espírito Santo, 2004)

[25] THAMES \& HUDSON. The great naturalists. Edited By Robert Huxley (New York: Thames and Hudson Inc., 2007)

[26] T. da BAVIERA, Viagem pelo Espírito Santo (1888): Viagem pelos trópicos brasileiros. Tradução e notas de Sara Baldus; organização e notas de Júlio Bentivoglio. (Vitória: Arquivo Público do Estado do Espírito Santo, 2013) 